\begin{tabular}{|l|l|l||}
\hline \multicolumn{2}{|c|}{ PublisherInfo } \\
\hline \hline PublisherName & $:$ & BioMed Central \\
\hline \hline PublisherLocation & $:$ & London \\
\hline \hline PublisherImprintName & $:$ & BioMed Central \\
\hline \hline
\end{tabular}

\title{
Ancient 'GM' corn
}

\begin{tabular}{|l|l|l||}
\hline \multicolumn{2}{|c|}{ ArticleInfo } \\
\hline \hline ArticleID & $:$ & 4882 \\
\hline \hline ArticleDOI & $:$ & $10.1186 /$ gb-spotlight-20031114-01 \\
\hline \hline ArticleCitationID & $:$ & spotlight-20031114-01 \\
\hline \hline ArticleSequenceNumber & $:$ & 234 \\
\hline \hline ArticleCategory & $:$ & Research news \\
\hline ArticleFirstPage & $:$ & 1 \\
\hline \hline ArticleLastPage & $:$ & 3 \\
\hline \hline & & RegistrationDate : 2003-11-14 \\
ArticleHistory & $:$ & OnlineDate \\
\hline \hline ArticleCopyright & $:$ & BioMed Central Ltd2003-11-14 \\
\hline \hline ArticleGrants & $:$ & \\
\hline \hline ArticleContext & $:$ & 130594411 \\
\hline \hline
\end{tabular}




\section{L Bishop}

Email: cleo.bishop@imperial.ac.uk

The ancestor of modern-day maize (Zea mays) has been the subject of fevered debate since the 1920s, with the most likely candidate being the wild grass teosinte. It is thought that contemporary maize arose from a single domestication event of teosinte parviglumisin the Balsas River Basin, Mexico, as early as 9000 years ago. What is remarkable is that the seeds required dispersal by prehistoric man. Previous work established that only five genomic regions were responsible for the phenotypic differences between teosinte and maize. Subsequently, three genes contributing to these differences have been cloned and characterized - the $t b 1$ and $p b f$ gene products control levels of kernel storage protein, while the sul gene encodes a starch debranching enzyme that is involved in corn tortilla texture. In the November 14 Science, Viviane Jaenicke-Després and colleagues at the Max Planck Institute for Evolutionary Anthropology compared DNA sequences of the $t b 1, p b f$, and $s u l$ from maize landraces from the Americas with those isolated from teosinte parviglumis. The authors identified modern corn alleles present within archaeological samples from 4000 years ago, suggesting that the genetic modification giving rise to these ancient plants resulted in superior crops that have been maintained as such for millennia (Science 2003, 302:1206-1208).

Jaenicke-Després et al. selected short DNA fragments ( $\sim 50 \mathrm{bp})$ suitable for the comparison of allelic frequency from archaeological remains. DNA was extracted from cob samples ranging from 4000 to 650 years old and cloned. Reconstruction of each gene was achieved by sequencing of multiple clones. Comparison of these sequences with those from modern day maize and teosinte samples confirmed modern alleles were present in Mexican maize some 4400 years ago. The phenotypic role of the three genes investigated suggests that cob size and kernel quality were used by prehistoric farmers to select next generation plants.

"By 4400 years ago, early farmers had already had a substantial homogenizing effect on allelic diversity at three genes associated with maize morphology and biochemical properties of the corn cob... As more genes involved in selected features become identified in maize as well as other crops, the ability to determine nuclear gene sequences from domesticated plants recovered from archaeological excavations will make it possible to follow comprehensively the genetic consequences of domestication over time," conclude the authors.

"The apparent loss of genetic diversity following the introduction of high-yielding Green Revolution wheat and rice varieties in the 1960s and 1970s, and attending the rapid adoption of superior GM [genetically modified] crops today, is far from a new phenomenon," comments Nina V. Fedoroff from the Huck Institute for Life Sciences in an accompanying article. 


\section{References}

1. A single domestication for maize shown by multilocus microsatellite genotyping

2. Mapping the genes that made maize

3. Science, [http://www.sciencemag.org]

4. Max Planck Institute for Evolutionary Anthropology, [http://www.eva.mpg.de]

5. Huck Institute for Life Sciences, [http://www.lsc.psu.edu/] 